\title{
PENINGKATAN PRESTASI BELAJAR MATEMATIKA DENGAN METODE JARIMATIKA PADA MATERI MENGURUTKAN BILANGAN PADA SISWA KELAS III SDN 5 MADUREJO TAHUN AJARAN 2017/2018
}

\author{
UTIN SANIAH, S.Pd. SD \\ NIP. 196710151987122002
}

\section{SDN 5 MADUREJO}

\begin{abstract}
Abstrak
Tujuan pengajaran matematika di sekolah dasar adalah menumbuhkan dan mengembangkan keterampilan berhitung menumbuhkan kemampuan siswa yang dapat dialihgunakan serta membentuk sikap logis, kritis, cermat, kreatif, dan disiplin. Bahan kajian inti matematika di SD mencakup aritmetika (berhitung), pengantar aljabar, geometri, pengukuran, dan kajian data. Penekanan diberikan pada penguasaan bilangan. Matematika memiliki ciri-ciri khusus yaitu abstrak, berpola pikir deduktif dan konsisten. Dari pengamatan di lapangan diketahui penguasaan matematika siswa kelas III pada pokok bahasan Mengurutkan bilangan sangat rendah, menurut Piaget perkembangan kognitifnya sedang berada pada operasional konkret. Penerapan teori Piaget menyatakan bahwa pada tahap operasional konkret anak sudah dapat berpikir logis tetapi masih memerlukan benda-benda konkret untuk membantu pemikirannya.

Tahap pra siklus ini bertujuan untuk mengetahui seberapa jauh Prestasi Belajar peserta didik dalam pembelajaran matematika pada materi Mengurutkan bilangan sebelum diterapkannya metode jarimatika. Pelaksanaan kegiatan pembelajaran untuk prasiklus dilaksanakan pada tanggal 11 September 2017. Pada tahap ini, peneliti mengamati kegiatan pembelajaran matematika materi Mengurutkan bilangan secara langsung di kelas III SDN 5 Madurejo. Dalam proses pembelajaran materi Mengurutkan bilangan tersebut guru masih menggunakan metode hafalan. Guru memberikan materi Mengurutkan bilangan dengan cara menghafal dan setelah itu langsung memberikan soal latihan Mengurutkan bilangan. Data dikumpulkan dengan menggunakan instrumen observasi yang dipegang oleh peneliti dan lembar soal. Lembar soal ini adalah sebagai tes kemampuan untuk mengetahui kemampuan peserta didik dalam memahami materi sebelum diterapkannya metode jarimatika.
\end{abstract}

Kata Kunci: Prestasi Belajar, Metode Jarimatika

\section{PENDAHULUAN}

Penekanan diberikan pada penguasaan bilangan. Matematika memiliki ciri-ciri khusus yaitu abstrak, berpola pikir deduktif dan konsisten. Dari pengamatan di lapangan diketahui penguasaan matematika siswa kelas III pada pokok bahasan Mengurutkan bilangan sangat rendah, menurut Piaget perkembangan kognitifnya sedang berada pada operasional konkret. Penerapan teori Piaget menyatakan bahwa pada tahap operasional konkret anak sudah dapat berpikir logis tetapi masih memerlukan benda-benda konkret untuk membantu pemikirannya. Sementara guru cenderung mengajar matematika secara simbolik sehingga bertentangan dengan kemampuan kognitif siswa. Teknik pembelajaran hanya mementingkan hasil belajarnya saja tanpa memperhatikan proses belajar mengajar Guru harus lebih banyak menjelaskan, tetapi penanaman konsep dasar kurang diperhatikan. Faktor lain yang mempengaruhi belajar siswa adalah sebagai berikut :

1. Guru saat mengajar tidak menggunakan metode karena keterbatasan waktu dan fasilitas serta keberadaan guru itu 
sendiri, sehingga hasilnya tidak seperti yang diharapkan.

2. Faktor lingkungan juga sangat mempengaruhi apalagi keberadaan masyarakat desa kebanyakan berpendidikan rendah dan tidak memiliki pekerjaan yang pasti.

3. Faktor jaman globalisasi dan reformasi yang menimbulkan sifat- sifat manusia menjadi berubah kejalan yang salah. Sehingga kurang perhatian terhadap kemajuan pendidikan pada umumnya

Terbukti bahwa sekarang anak-anak sekolah sudah tidak mau belajar bahkan yang ditunggu-tunggu acara televisi, lucunya para orang tua murid tidak mendorong anaknya untuk belajar, seolah-olah menyepelekan hal pendidikan. Padahal esok harinya ada tugas PR Matematika, bagaimana hasil belajar akan meningkat jika hal ini tetap dibiarkan.

Salah satu metode yang diharapkan dapat meningkatkan kemampuan berhitung serta menggairahkan semangat belajar siswa, karena metodenya merupakan kegiatan yang menyerupai permainan yang menyenangkan, metode yang dipakai adalah metode jarimatika yang menggunakan 10 jari sebagai alat bantu untuk proses berhitung Mengurutkan bilangan. Jarimatika memberikan visualisasi proses berhitung. Hal ini akan membuat siswa mudah melakukannya. Melalui metode jarimatika, siswa tidak perlu membeli untuk alat peraga karena metode ini sangat praktis dengan menggunakan jari-jari tangan sebagai alat berhitung.

Banyak faktor yang menyebabkan rendahnya prestasi belajar matematika siswa SDN 5 Madurejo Tahun Pelajaran 2017/2018, baik yang berasal dalam dalam diri murid itu sendiri maupun yang berasal dari luar diri murid. Faktor dari dalam diri murid misalnya, motivasi belajar, minat belajar, sikap terhadap matematika, serta kemampuan berfikir konvergen dan divergen. Sedangkan faktor yang berasal dari luar misalnya kemampuan guru dalam mengelola proses belajar, sarana belajar, dan lingkungan pendukung.

Dalam kurikulum siswa SD sudah mulai diperkenalkan dengan Mengurutkan bilangan pada Kelas III. Mengurutkan bilangan biasa diajarkan di Kelas III,. Dalam kenyataannya siswa dalam mempelajari Mengurutkan bilangan masih nampak mengalami kesulitan. Dengan demikian murid akan mengalami kesulitan dalam menyelesaikan soal-soal pada pokok bahasan lain yang dikaitkan dengan topik tersebut. Berdasarkan pemikiran tersebut, maka dianggap perlu untuk melakukan penelitian tentang kemampuan dan penguasaan Mengurutkan bilangan Kelas III SDN 5 Madurejo Tahun Pelajaran 2017/2018.

\section{TINJAUAN PUSTAKA}

Berdasarkan telaah pustaka yang telah penyusun lakukan, tentang penggunaan metode Jarimatika, peneliti telah menemukan beberapa data- data kepustakaan penting sebelumnya, di antaranya:

Pertama, penelitian yang dilakukan oleh Lidya Anita Sari. Fakultas Ilmu Keguruan dan Ilmu Pendidikan Universitas Muhamadiyah Yogyakarta tahun 2010 dengan judul "Optimalisasi Penggunaan Jarimatika untuk Meningkatkan Ketrampilan Berhitung Pembagian Bilangan Bulat Positif". Didapatkan hasil penelitian berupa peningkatan Ketrampilan belajar siswa dengan bukti peningkatan nilai dari setiap siklus yang dilakukan dalam penelitian.

Kedua, penelitian yang dilakukan oleh Djunedi Mudji Iswanto Fakultas Matematika dan Ilmu Pengetahuan Alam Universitas Negeri Semarang tahun 2006 dengan judul "Upaya Meningkatkan Prestasi / Hasil Belajar Siswa Kelas IV Semester I SD Negeri Pandeglang 01 Kecamatan Dukuhwaru Kabupaten Tegal Dalam Pokok Bahasan Bilangan Dan Lambangnya Melalui Pemanfaatan Alat Peraga Benda Konkrit Tahun Pelajaran 2005/2006". Didapatkan hasil bahwa penelitian dapat meningkatkan hasil belajar ranah kognitif, minat belajar dalam mengikuti pelajaran cukup tinggi dan suasana kelas lebih menarik dan juga aktif.

Ketiga, penelitian yang dilakukan oleh Yeni Kurniawati Fakultas Pendidikan Matematika Universitas Muhamadiyah Malang tahun 2009 dengan judul "Studi Komparasi Hasil Belajar Matematika Antara Yang Menggunakan Metode Jarimatika 
Dengan Metode Konvensional Pada Siswa Kelas IV Di SDN Krian III Sidoarjo". Didapatkan hasil penelitian yang lebih baik dibandingkan dengan pembelajaran tanpa bantuan Jarimatika, membantu dalam mengatasi kesulitan belajar, minat siswa tinggi, suasana belajar lebih menarik dan lebih aktif.

\section{A. Landasan Teori}

\section{Pengertian Belajar}

Menurut beberapa ahli pendidikan telah merumuskan dan menafsirkan pengertian belajar. Adanya perbedaan belajar justru menjadi khasanah pengetahuan tentang belajar agar relevan dengan tujuan utama penelitian ini maka hal pertama yang akan dibahas adalah pengertian belajar dan faktor-faktor yang mempengaruhinya. Selanjutnya bertolak dari adanya perbedaan dan persamaan dalam sejumlah faktor antara siswa yang satu dengan yang lain akan dibahas sistem pembelajaran dengan model pemanfaatan metode. menuliskan definisi belajar adalah proses perubahan yang relatif dalam perilaku individu sebagai hasil dari pengalaman. Definisi tersebut memusatkan perhatian kepada hal-hal sebagai berikut: Bahwa belajar harus memungkinkan terjadinya perubahan perilaku individu Bahwa perubahan itu harus merupakan buah dari pengalaman.

\section{belajar}

2. Faktor-faktor yang mempengaruhi

Melihat proses belajar secara keseluruhan perlu diingat adanya sejumlah faktor yang mempengaruhi. faktor-faktor yang mempengaruhi proses dan hasil belajar adalah sebagai berikut :

1) Faktor Internal

a) Sikap terhadap belajar

b) Motivasi belajar

c) Konsentrasi belajar

d) Mengolah bahan pelajaran

e) Menyimpan perolehan hasil belajar

e) Menyimpan perolehan hasil belajar

f) Rasa percaya diri

g) Intelegensi dan keberhasilan belajar

h) Kebiasaan belajar

2) Faktor Eksternal

a) Guru sebagai pembina siswa belajar b) Sarana dan prasarana

c) Kebijaksanaan penilaian

d) Lingkungan sosial siswa di sekolah

\section{Prestasi belajar matematika}

Prestasi adalah hasil yang telah dicapai, dilakukan, dikerjakan dan sebagainya. Sedangkan yang dimaksud belajar yaitu suatu Proses usaha yang dilakukan individu untuk memperoleh suatu perubahan tingkah laku baru secara keseluruhan pengalaman individu itu sendiri interaksi dengan lingkungannya. Jadi yang dimaksud dengan prestasi belajar yaitu suatu hasil yang telah dicapai siswa terhadap sejumlah materi tertentu dalam rangka untuk memperoleh suatu perubahan, baik perubahan segi pengetahuan, keterampilan maupun sikap

\section{Pengertian Metode}

Metode yang sering disebut "audio visual" adalah alat yang dapat diserap oleh mata telinga sebagai alat bantu dalam proses belajar mengajar, agar hasil belajar mencapai optimal. Tampilnya metode pada mulanya ditujukan sebagai salah satu usaha untuk mencegah verbalisme dalam pendidikan, metode sebagai sumber media atau perlengkapan yang digunakan guru mengajar. Sedangkan Tim PKG menyatakan metode merupakan benda-benda konkret sebagai model dan ide-ide matematika dan penerapannya. Metode adalah benda- benda konkret yang merupakan model dan ide-ide matematika. mengungkapkan metode merupakan alat bantu pengajaran yang mudah memberi pengertian kepada peserta didik.

\section{Pengertian Jarimatika}

Jarimatika adalah cara berhitung dengan mudah dan Menyenangkan (Operasi KaliBagi-Tambah-Kurang) dengan menggunakan jari-jari tangan.

\section{B. Hipotesis}

Dengan menggunakan metode jarimatika, prestasi belajar matematika pada materi Mengurutkan bilangan siswa kelas III SDN 5 Madurejo Tahun Pelajaran 2017/2018 akan meningkat.

\section{METODE PENELITIAN}




\section{A. Jenis Penelitian dan Pendekatan Penelitian}

Penelitian ini menggunakan jenis Penelitian Tindakan Kelas (Clasroom Action Research). Penelitian Tindakan Kelas (PTK) merupakan sebuah kegiatan penelitian yang bertujuan untuk memperbaiki kekurangan kekurangan yang terdapat dalam pembelajaran di kelas, yaitu dengan cara melakukan tindakan - tindakan tertentu agar dapat memperbaiki serta meningkatkan kualitas pembelajaran sehingga tujuan pembelajaran yang diharapkan dapat tercapai.

\section{B. Subjek dan Objek Penelitian}

Subjek dalam penelitian ini adalah siswa kelas III SDN 5 Madurejo Tahun Pelajaran 2017/2018. Sedangkan objek dalam penelitian ini adalah hasil prestasi belajar matematika pada materi Mengurutkan bilangan siswa kelas III SDN 5 Madurejo Tahun Pelajaran 2017/2018 dengan metode Jarimatika.

Tabel 1 Subjek penelitian

\begin{tabular}{|c|c|}
\hline NO & NAMA \\
\hline 1 & \\
\hline 2 & \\
\hline 3 & \\
\hline 4 & \\
\hline 5 & \\
\hline 6 & \\
\hline 7 & \\
\hline 8 & \\
\hline 9 & \\
\hline 10 & \\
\hline 11 & \\
\hline 12 & \\
\hline 13 & \\
\hline 14 & \\
\hline 15 & \\
\hline 16 & \\
\hline 17 & \\
\hline 18 & \\
\hline 19 & \\
\hline 20 & \\
\hline 21 & \\
\hline 22 & \\
\hline
\end{tabular}

\begin{tabular}{|l|l|}
\hline 23 & \\
\hline 24 & \\
\hline 25 & \\
\hline 26 & \\
\hline 27 & \\
\hline 28 & \\
\hline
\end{tabular}

\section{Instrumen Penelitian}

Instrument penelitian merupakan alat ukur yang digunakan untuk mendapatkan informasi tentang karakteristik data secara objektif.
i. Peneliti
ii. Lembar Observasi
iii. Wawancara
iv. Catatan Lapangan
v. Lembar Kerja Siswa
vi. Dokumentasi

\section{Teknik Pengumpulan Data}

Teknik atau metode penelitian adalah cara atau sistem yang ditempuh dalam riset yang diatur secara baik.

\section{E. Uji Keabsahan Data}

Untuk menjaga keabsahan data, dalam penelitian ini peneliti berperan sebagai pengamat dan guru sebagai penyampai materi atau berkolaborasi. Uji keabsahan data menggunakan teknik triangulasi. Teknik triangulasi adalah teknik pemeriksaan keabsahan data yang memanfaatkan sesuatu yang lain. Adapun teknik triangulasi sumber, berarti membandingkan data dan mengecek kembali derajat kepercayaan yang diperoleh melaui waktu dan nilai berbeda dalam metode kualitatif.

\section{F. Teknik Analisis Data}

Teknik analisis data adalah cara atau sistem yang digunakan seorang peneliti untuk menganalisis data yang telah dikumpulkan sebagai sesuatu yang harus dilalui sebelum mengambil kesimpulan.

G. Rancangan Penelitian

Model atau desain yang digunakan dalam Penelitian Tindakan Kelas (PTK) ini 
adalah model Kemmis dan Taggart, dimana dalam satu siklus terdiri dari 4 komponen yaitu planning (perencanaan), acting (tindakan), observing (observasi), dan reflecting (refleksi).

Hubungan antara komponen tindakan menunjukkan sebuah siklus atau kegiatan berkelanjutan berulang. Keputusan untuk menghentikan atau melanjutkan penelitian adalah kesepakatan antara guru dan peneliti, yaitu jika proses pembelajaran dengan Pemanfaatan Metode Jarimatika yang telah dilakukan sesuai dengan rencana dan prestasi belajar siswa telah meningkat atau mencapai kategori baik. Prosedur penelitian ini terdiri dari dua siklus, yaitu :

1. Siklus I

1. Perencanaan (planning)

Tahap perencanaan dimulai dengan penemuan masalah di lapangan. Tahap ini dilakukan melalui pengamatan awal di SDN 5 Madurejo Tahun Pelajaran 2017/2018 secara keseluruhan, yang meliputi pengamatan proses pembelajaran di kelas, wawancara serta diskusi dengan kepala sekolah, guru mata pelajaran, dan wawancara dengan bagian kurikulum kesiswaan.

Dari hasil pengamatan dan diskusi tersebut ditemukan beberapa masalah yang perlu segera mendapatkan pemecahan. Masalah-masalah tersebut telah diuraikan secara jelas dalam identifikasi masalah. Peneliti dengan pihak terkait yaitu guru mata pelajaran Matematika mendiskusikan rancangan yang berisi langkah-langkah atau perlakuan yang harus diberikan untuk mengatasi masalah - masalah tersebut. Rencana ini bersifat fleksibel dan terbuka terhadap perubahan-perubahan yang terjadi saat pelaksanaannya.

2. Pelaksanaan tindakan ( action )

Tindakan merupakan penerapan dari perencanaan yang telah dibuat yang dapat berupa suatu penerapan model pembelajaran tertentu yang bertujuan untuk memperbaiki atau menyempurnakan model yang sedang dijalankan. Pada tahap ini guru melakukan pembelajaran melalui Pemanfaatan Metode
Jarimatika sesuai dengan rencana yang telah disusun yang bersifat fleksibel, maka rencana dapat berubah sesuai dengan keadaan di lapangan pada saat pelaksanaan.

\section{Observasi (observation)}

Kegiatan ini dilakukan bersamaan dengan tahap pelaksanaan tindakan sebagai upaya untuk mengetahui pelaksanaan pembelajaran melalui Pemanfaatan Metode Jarimatika berlangsung serta segala aktivitas yang dilakuakn guru maupun siswa selama pembelajaran. Sehingga ketika tindakan sedang dilakuakn maka tindakan tersebut langsung diamati bagaimana prosesnya, efeknya, keefektifannya dalam mengatasi masalah dalam pembelajaran. Setelah observasi dilakukan, diberikan tes diagnostik berupa soal - soal yang dikerjakan secara individu untuk mengetahui kesulitan dalam belajar dan peningkatan prestasi siswa.

\section{Refleksi (reflection)}

Refleksi merupakan tahap penilaian terhadap proses yang terjadi, masalah yang muncul, serta segala hal yang berkaitan dengan tindakan yang dilakukan. Pelaksanaan refleksi ini adalah melalui diskusi dari pihak yang terkait dalam penelitian. Hasil dari refleksi adalah diadakannya revisi terhadap perencanaan yan telah dilaksanakan, yang akan dipergunakan untuk memperbaiki kinerja guru pada pertemuan selanjutnya.

Berdasarkan refleksi ini maka dapat ditarik kesimpulan tindakan-tindakan apa saja yang memenuhi harapan, apa yang belum, apa yang harus dipertahankan atau bahkan dimantapkan, serta tindakan apa yang harus direvisi kembali, yang selanjutnya dapat disusun rencana untuk putaran berikutnya yaitu siklus II.

\section{Siklus II}

Pada siklus kedua ini, langkah kerja yang dilakukan mengikuti siklus pertama, dimana tindakan dalam siklus kedua disusun berdasarkan refleksi siklus pertama dan tindakan yang akan dilakukan dimaksudkan sebagai perbaikan dan penyempurnaan tindakan yang dilakukan pada siklus pertama. 


\section{HASIL PENELITIAN \\ PEMBAHASAN}

\section{A. HASIL PENELITIAN}

\section{Deskripsi Data Pra Siklus}

Tahap pra siklus ini bertujuan untuk mengetahui seberapa jauh Prestasi Belajar peserta didik dalam pembelajaran matematika pada materi Mengurutkan bilangan sebelum diterapkannya metode jarimatika. Pelaksanaan kegiatan pembelajaran untuk prasiklus dilaksanakan pada tanggal 11 September 2017.

Pada tahap ini, peneliti mengamati kegiatan pembelajaran matematika materi Mengurutkan bilangan secara langsung di kelas III SDN 5 Madurejo. Dalam proses pembelajaran materi Mengurutkan bilangan tersebut guru masih menggunakan metode hafalan. Guru memberikan materi Mengurutkan bilangan dengan cara menghafal dan setelah itu langsung memberikan soal latihan Mengurutkan bilangan.

Data dikumpulkan dengan menggunakan instrumen observasi yang dipegang oleh peneliti dan lembar soal. Lembar soal ini adalah sebagai tes kemampuan untuk mengetahui kemampuan peserta didik dalam memahami materi sebelum diterapkannya metode jarimatika.

Berdasarkan hasil pengamatan Prestasi Belajar peserta pada pra siklus didapatkan data sebagai berikut:

\section{a. Keaktifan}

Hasil pengamatan peneliti terhadap keaktifan peserta didik dalam proses pembelajaran materi Mengurutkan bilangan dasar sebelum diterapkan metode jarimatika dipersentasekan pada tabel berikut ini.

Tabel 2 Keaktifan Belajar Pra Siklus

\begin{tabular}{|l|l|c|}
\hline No & Aspek Yang Diamati & Nilai \\
\hline 1 & $\begin{array}{l}\text { Kesiapan peserta didik menerima } \\
\text { pelajaran }\end{array}$ & 34 \\
\hline 2 & $\begin{array}{l}\text { Keaktifan dalam bertanya dan } \\
\text { menjawab }\end{array}$ & 32 \\
\hline 3 & Memperhatikan penjelasan guru & 31 \\
\hline 4 & $\begin{array}{l}\text { Kerjasama peserta didik dalam } \\
\text { pembelajaran }\end{array}$ & 30 \\
\hline 5 & Ketepatan mengerjakan test & 33 \\
\hline & Jumlah Skor & 160 \\
\hline & Rata-Rata & 32 \\
\hline & Kriteria & Kurang \\
\hline
\end{tabular}

\begin{tabular}{|l|l|}
\hline Persentase & $38 \%$ \\
\hline Keterangan: & \\
Kriteria Penilaian & \\
$1-17:$ Sangat Kurang & \\
$18-34:$ Kurang & \\
$35-51:$ Cukup & \\
$52-68:$ Baik & \\
$69-85:$ Sangat Baik
\end{tabular}

Berdasarkan hasil tabel di atas dapat disimpulkan bahwa peserta didik belum terlibat aktif secara penuh dalam proses pembelajaran, hal tersebut dapat dilihat dari nilai rata- rata keaktifan yang menunjukkan angka 32 atau dengan kriteria kurang karena hanya $38 \%$ saja peserta didik yang aktif sedangkan indikator keaktifan yang ditentukan adalah sebesar $75 \%$. Keaktifan peserta didik adalah sebagai indikator adanya semangat belajar dalam proses pembelajaran dan semangat belajar ini menunjukkan adanya keinginan untuk bisa yang pada akhirnya dapat meningkatkan hasil belajar.

\section{b. Hasil Belajar}

Hasil pengamatan peneliti terhadap hasil belajar peserta didik dalam proses pembelajaran materi Mengurutkan bilangan dasar sebelum diterapkan metode jarimatika dipersentasekan sebagaiberikut.

Jumlah siswa yang tuntas belajar $\mathrm{X} 100$

Persentase =<smiles>[AlH2]</smiles>

$\mathrm{ml}$ ah sis W a

$=7 / 17$

$=41,2 \%$

Dan berikut ini adalah tabel dan grafik hasil belajar peserta didik pada tahap pra siklus.

Tabel 3

Ketuntasan Hasil Belajar Pra Siklus No Ketuntasan Jumlah Siswa 


\begin{tabular}{|c|c|c|c|c|c|c|c|}
\hline & \multirow[t]{2}{*}{ Belajar } & \multirow[b]{2}{*}{ Jumlah } & \multirow[b]{2}{*}{ Persen } & 1 & Tuntas & 10 & $41,2 \%$ \\
\hline & & & & & & & \\
\hline 2 & Belum Tuntas & 18 & $58,8 \%$ & & & & \\
\hline
\end{tabular}

\section{Deskripsi Data Siklus I} Siklus I

a. Penerapan Metode Jarimatika Pada

Penerapan metode jarimatika merupakan metode yang berkaitan erat dengan model pembelajaran langsung. Secara garis besar dalam model pembelajaran langsung terdapat 5 (lima) langkah, yaitu: persiapan, demontrasi, pelatihan terbimbing, umpan balik, dan pelatihan lanjut (mandiri). Adapun proses belajar mengajar mengacu pada skenario pembelajaran yang termuat dalam rencana pelaksanaan pembelajaran yang telah disiapkan. Pokok bahasan yang diajarkan adalah mengerjakan hitung Mengurutkan bilangan bilangan satu angka dengan menggunakan metode jarimatika.

Pelaksanaan tindakan untuk siklus I dilaksanakan pada tanggal 20 September 2018. Dalam penelitian ini peneliti bertindak sebagai observer dan kolabolator bertindak sebagai guru. Sebelum melaksanakan tindakan peneliti mempersiapkan rencana kegiatan harian selama penelitian berlangsung, menentukan target pencapaian rata- rata kelas dan prosentase ketuntasan minimal, mengidentifikasi masalah, menyiapkan sarana prasarana, lembar pengamatan dan lembar penilaian.Target pencapaian ketuntasan minimal yang ditentukan adalah $65 \%$ dan keaktifannya $75 \%$.

Grafik 1 Ketuntasan Hasil Belajar Siklus I

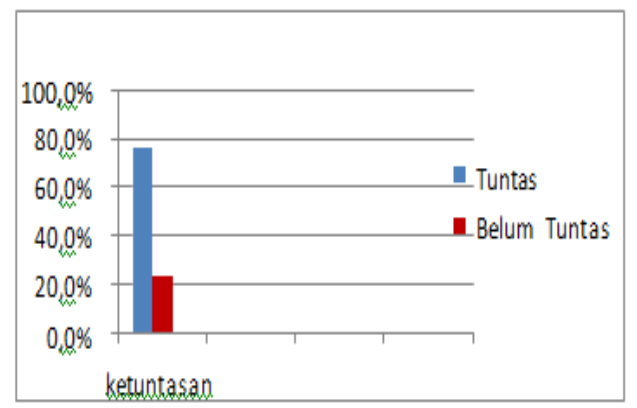

Berdasarkan tabel di atas, hasil test akhir pada tahap siklus ini I di dapat bahwa ketuntasan belajar peserta didik meningkat. Dari data yang diperoleh hanya 4 peserta didik yang belum tuntas. Hasil tes didapatkan nilai tertinggi adalah 100 , nilai terendah 35 , dan nilai rata-rata 76,8 . Dari data tersebut hanya $76,4 \%$ peserta didik yang tuntas dan selebihnya $23,6 \%$ belum tuntas dan keaktifan yag didapat hanya $69 \%$ di bawah keaktifan yang ditentukan yaitu $75 \%$. Hal ini disebabkan karena peserta didik masih belum menguasai konsep jarimatika dan guru kurang memberi bimbingan secara individu.

\section{Deskripsi Data Siklus II}

a) Penerapan Metode Jarimatika Pada Siklus II

Pelaksanaan kegiatan belajar mengajar untuk siklus II dilaksanakan pada tanggal 27 September 2017. Pada tahap ini guru mempersiapkan rencana kegiatan harian selama penelitian berlangsung, menentukan target pencapaian rata- rata kelas dan prosentase ketuntasan minimal, mengidentifikasi masalah, menyiapkan sarana prasarana, lembar pengamatan dan lembar penilaian.

Peneliti menentukan identifikasi masalah yaitu keaktifan peserta didik pada siklus I yang belum sesuai dengan persentase ketuntasan minimal. Target pencapaian ketuntasan minimal $65 \%$ dan keaktifan mencapai $75 \%$.

\section{B. Pembahasan}

1. Hasil Penelitian Siklus I

a) Penerapan Metode Jarimatika

Penerapan metode jarimatika dalam pembelajaran siklus I belumlah optimal karena peserta didik masih kesulitan dalam mempraktekkan jarimatika. Hal ini disebabkan karena guru kurang memberikan latihan dan bimbingan secara individu kepada peserta didik yang mengalami kesulitan dalam mempraktekkan jarimatika. Selain itu, guru sebagai kolabolator juga kurang menguasai 
skenario pembelajaran sehingga pembelajaran belum optimal dan kurang baik dalam memeratakan perhatian kepada peserta didik selama pembelajaran berlangsung. Oleh karena itu, pada tindakan selanjutnya yaitu siklus II, guru harus memberikan perbaikan diantaranya;

1. Lebih mengusai skenario pembelajan dengan lebih baik.

2. Lebih banyak memberikan latihan dan bimbingan secara individu kepada peserta didik yang mengalami kesulitan dalam mempraktekkan jarimatika.

3. Lebih memeratakan perhatian kepada peserta didik selama pembelajaran berlangsung.

1) Keaktifan

Pencapaian keaktifan belajar peserta didik pada siklus I sebesar $69 \%$, jauh lebih besar dari hasil keaktifan sebelum dilaksanakannya penelitian tindakan kelas yaitu 38\%. Sebelum dilakukan tindakan keaktifan peserta didik berada dalam kategori kurang yaitu dengan nilai rata-rata 32 dan setelah dilakukan tindakan keaktifan peserta didik berada dalam kategori baik yaitu dengan nilai rata-rata 59.

Dari lima aspek keaktifan yang diamati semuanya mengalami kenaikan baik dari kesiapan peserta didik dalam menerima pelajaran hingga ketepatan mengerjakan soal tes. Pada siklus I kesiapan peserta didik dalam menerima pelajaran hanya meningkat sebesar $29 \%$, keaktifan dalam bertanya dan menjawab meningkat $28 \%$, memampuan memperhatikan guru meningkat $36 \%$, kerja sama meningkat $33 \%$, dan ketepatan mengerjakan tes meningkat $33 \%$.

Walaupun kenaikannya tidak secara signifikan hal ini dapat dijadikan indikator bahwa peserta didik mulai mempunyai semangat dalam proses pembelajaran.

2) Hasil Belajar

Hasil belajar peserta didik menggunakan metode jarimatika pada siklus I menunjukkan nilai tertinggi adalah 100 , nilai terendah 35 , dan nilai rata-rata 76,8. Dari data tersebut hanya $76,4 \%$ peserta didik yang tuntas dan selebihnya $23,6 \%$ belum tuntas.
Hasil tes yang diperoleh tersebut digunakan untuk mengetahui peningkatan hasil belajar peserta didik sebelum dan sesudah penerapan metode jarimatika ,.

Berdasarkan evaluasi terhadap hasil belajar tersebut menunjukkan bahwa meskipun telah tercapai ketuntasan klasikal namun ada 4 anak yang belum tuntas, nilai mereka masih jauh dari KKM yang ditentukan. Dari 15 soal tes yang diberikan mereka hanya dapat menjawab 3 sampai 4 soal. Nilai mereka yang rendah yaitu berkisar antara 35 hingga 45 , dan hal ini disebabkan karena mereka masih binggung memainkan jari-jari mereka.

Rekomendasi perlu dilanjutkan ke siklus II, dengan komposisi materi soal yang berbeda dan memberikan bimbingan khusus kepada mereka.

\section{Hasil Penelitian Siklus II}

a. Penerapan Metode Jarimatika

Sebelum melakukan tindakan pada siklus II, peneliti dan guru mendiskusikan hasil refleksi proses pembelajaran saat penerapan metode jarimatika, pada siklus I. Pada siklus I didapatkan beberapa permasalahan diantaranya yaitu peserta didik kurang aktif karena masih kesulitan dalam mempraktekkan jarimatika, guru kurang menguasai skenario pembelajaran, dan guru kurang memberikan bimbingan secara individu kepada peserta didik yang mengalami kesulitan dalam mempraktekkan jarimatika.

Pada siklus II penerapan metode jarimatika hasilnya sangat optimal. Hal ini dikarenakan guru sudah sangat mengusai skenario pembelajarn dengan lebih baik, lebih banyak memberikan latihan dan bimbingan secara individu kepada peserta didik yang mengalami kesulitan dalam mempraktekkan jarimatika,dan lebih memeratakan perhatian kepada peserta didik selama pembelajaran berlangsung.

\section{1) Keaktifan}

Pencapaian keaktifan belajar peserta didik pada siklus II sebesar $81 \%$ dan angka ini jauh lebih besar dari hasil keaktifan sebelum dilaksanakannya penelitian tindakan kelas yaitu 38\%. Sebelum dilakukan tindakan keaktifan peserta didik berada dalam kategori 
Utin Saniah. Peningkatan Prestasi Belajar Matematika Dengan Metode Jarimatika Pada Materi Mengurutkan Bilangan Pada Siswa Kelas III SDN 5 Madurejo Tahun Ajaran 2017/2018

kurang yaitu dengan nilai rata-rata 32, pada siklus I nilai rata-rata menjadi 59 atau dalam kategori baik sedangkan pada siklus II ratarata keaktifan meningkat menjadi 69,2 atau meningkat sebesar $43 \%$ dari sebelum tindakan.

Dari lima aspek keaktifan yang diamati semuanya mengalami kenaikan baik dari kesiapan peserta didik dalam menerima pelajaran hingga ketepatan mengerjakan soal tes. Pada siklus II kesiapan peserta didik dalam menerima pelajaran, bertanya, dan menjawab meningkat sebesar $41 \%$. Kemampuan memperhatikan guru meningkat $43 \%$, kerja sama meningkat $49 \%$, dan ketepatan mengerjakan tes meningkat $46 \%$. Kenaikan yang secara signifikan ini menandakan bahwa peserta didik sudah mempunyai semangat yang tinggi dalam proses pembelajaran.

2) Hasil Belajar

Hasil belajar peserta didik menggunakan metode jarimatika , pada siklus II menunjukkan nilai tertinggi adalah 100 , nilai terendah 65 , dan nilai rata-rata 81,8 dengan ketuntasan $100 \%$ sehingga pembelajaran dikatakan sudah memenuhi indikator yang telah ditentukan yaitu minimal $75 \%$ dari jumlah siswa mencapai hasil belajar tuntas. Maka secara keseluruhan telah terjadi peningkatan hasil belajar peserta didik pada siklus II sehigga tindakan penelitian dihentikan sampai siklus II.

Hasil belajar yang signifikan ini menunjukkan bahwa metode jarimatika sangat efektif digunakan pada materi Mengurutkan bilangan dasar.

Penerapan metode jarimatika merupakan metode yang berkaitan erat dengan model pembelajaran langsung. Secara garis besar dalam model pembelajaran langsung terdapat 5 (lima) langkah, yaitu: persiapan, demontrasi, pelatihan terbimbing, umpan balik, dan pelatihan lanjut (mandiri).

Berdasarkan analisis data penerapan model pembelajaran langsung dalam metode jarimatika, untuk materi Mengurutkan bilangan dasar maka pada siklus I didapatkan beberapa permasalahan diantaranya yaitu peserta didik kurang aktif karena masih kesulitan dalam mempraktekkan jarimatika, guru kurang menguasai skenario pembelajaran, dan guru kurang memberikan bimbingan secara individu kepada peserta didik yang mengalami kesulitan dalam mempraktekkan jarimatika.

Dan pada siklus II peneliti dan guru kolabolator telah melakukan perbaikan dalam proses pembelajaran sehingga dari hasil pengamatan pada siklus II ini guru sudah lebih mengusai skenario pembelajaran dengan lebih baik, guru sudah banyak memberikan latihan dan bimbingan secara individu kepada peserta didik yang mengalami kesulitan dalam mempraktekkan jarimatika, dan guru harus sudah dapat memeratkan perhatian kepada peserta didik selama pembelajaran berlangsung.

Dengan membiasakan peserta didik melakukan latihan secara berulang maka hasil belajar Mengurutkan bilangan dasar peserta didik kelas III SDN 5 Madurejo mengalami peningkatan. Hal ini menunjukkan bahwa penerapan metode jarimatika, adalah efektif.

\section{PENUTUP}

\section{A. Kesimpulan}

Berdasarkan hasil penelitian dan pembahasan dapat disimpulkan hal- hal sebagai berikut :

1. Prestasi belajar peserta didik pada materi Mengurutkan bilangan sebelum menggunakan metode Jarimatika di SDN 5 Madurejo Tahun Pelajaran 2017/2018 masih di bawah KKM. Sedangkan KKM yang ditentukan pada kelas III adalah 6,1. Hasil prestasi belajar siswa di bawah KKM ini disebabkan karena metode pembelajaran kurang menarik bagi peserta didik.

2. Pelaksanaan Metode Jarimatika pada mata pelajaran Matematika pokok bahasan Mengurutkan bilangan di Kelas III SDN 5 Madurejo Tahun Pelajaran 2017/2018 dapat dilaksanakan melalui dua siklus. Siklus I siswa diberikan soal tentang materi Mengurutkan bilangan menggunakan metode jarimatika yang diajarkan oleh guru, sehingga menunjukkan peningkatan prestasi belajar. Pada siklus I rata-rata kelas menjadi 55,56. Hasil dari Siklus I belum maksimal, untuk itu 
peneliti melaksanakan Siklus II. Dalam Siklus II siswa diberikan soal Mengurutkan bilangan dan masih menggunakan metode jarimatika yang tingkat kesulitannya lebih tinggi daripada Siklus I. Hasil dari tes Siklus II mengalami peningkatan, rata-rata kelas menjadi 88,33. Dan dari hasil observasi dapat diketahui bahwa motivasi siswa terhadap keaktifan pelajaran Matematika sangat baik setelah diterapkannya pembelajaran dengan Metode Jarimatika.

3. Hasil penelitian ini menunjukkan bahwa pada siklus I persentase ketuntasan klasikal 22,22 \%. Pada siklus II persentase ketuntasan klasikal $77,78 \%$. Hal ini menunjukkan bahwa pembelajaran Matematika dengan metode Jarimatika dapat meningkatkan prestasi belajar Matematika pada materi Mengurutkan bilangan siswa kelas III SDN 5 Madurejo Tahun Pelajaran $2017 / 2018$.

\section{B. Saran-saran}

1. Kepada rekan guru

a. Penggunaan metode yang bervariasi akan membuat peserta didik semakin aktif dan tidak membosankan.

b. Memahami keadaan peserta didik akan lebih baik demi tercapainya tujuan pendidikan yang diharapkan.

2. Kepada peserta didik

a. Kerjasama dalam kelompok akan melatih belajar berorganisasi dalam lingkungan sekolah dan masyarakat.

b. Selalu tekun dan semangat dalam belajar.

3. Untuk peneliti

a. Hubungan yang baik dengan peserta didik akan memudahkan dalam interaksi di kelas sehingga apa yang disampaikan akan mudah diterima peserta didik.

b. Dalam memberikan perhatian kepada peserta didik sebaiknya jangan memilih, semua butuh dilayani dengan baik.

\section{Kata Penutup}

Demikianlah hasil Penelitian Tindakan Kelas yang telah peneliti lakukan pada siswa kelas III SDN 5 Madurejo Tahun Pelajaran 2017/2018 pada mata pelajaran Matematika materi Mengurutkan bilangan sehingga peneliti mampu menyelesaikan penulisan PTK ini sebagai salah satu syarat untuk kenaikan golongan.

Peneliti menyadari bahwa dalam penulisan skripsi ini baik secara pemilihan bahasa maupun bobot keilmuannya masih terdapat banyak kekurangan. Besar harapan kami atas saran, masukan, serta kritikan demi kesempurnaan skripsi ini. Semoga skripsi ini mampu memberikan manfaat bagi peneliti, pembaca, maupun dunia pendidikan pada umumnya. Amiin.

\section{DAFTAR PUSTAKA}

Ali, Muhammad, Penelitian Kependudukan Prosedur dan Strategi, Bandung: Angkasa, 1996

Arikunto, Suharsini, Prof, Dr, Prosedur Penelitian Suatu Pendekatan Praktek, Jakarta : PT. Rineka Cipta, 1998

Departemen Pendidikan Nasional, Kurikulum Tingkat Satuan Pendidikan, Jakarta: Balai Pustaka,2004

Mudji Iswanto, Djunedi, Upaya Meningkatkan Prestasi / Hasil Belajar Siswa Kelas IV Semester I SD Negeri Pandeglang 01 Kecamatan Dukuhwaru Kabupaten Tegal Dalam Pokok Bahasan Bilangan Dan Lambangnya Melalui Pemanfaatan Alat Peraga Benda Konkrit Tahun Pelajaran 2005 / 2006, Skripsi , Fakultas Matematika dan Ilmu Pengetahuan Alam Universitas Negeri Semarang, 2005.

Erman Suherman, Gagne, Metode Belajar Praktis, Jakarta:UNY Pres, 2001 Fakultas Ilmu Tarbiyah UIN Sunan Kalijaga Yogyakarta, Pedoman Penulisan 
Utin Saniah. Peningkatan Prestasi Belajar Matematika Dengan Metode Jarimatika Pada Materi Mengurutkan Bilangan Pada Siswa Kelas III SDN 5 Madurejo Tahun Ajaran 2017/2018

Skripsi, Yogyakarta : Fakultas Syariah Press,

2004

Fontana, Srategi Belajar Matematika, Jakarta:

Intan Pariwara, 1981

Hadi, Sutrisno, Metodhologi Research Jilid II,

Yogyakarta : Andi Offset, 1999

Johan Amos Cornellius pada tahun 1952 -

1971 dan dilanjutkan oleh John Jacque

Rouseu, Pestalozi, Maria Montesori, John

Dewey dan yang lain. Menurut Anderson

Ronal H. (1987 : 9), www.sardjanaku.com,

diakses tanggal 13 Maret 2018

Kuncoro Ningrat, Metode Penelitian

Masyarakat, Jakarta: Gramedia, 1990 Anita

Sari, Lidya, Optimaalisasi Penggunaan

Jarimatika untuk Meningkatkan

Ketrampilan Berhitung Pembagian Bilangan

Bulat Positif, Skripsi , Fakultas Ilmu

Keguruan dan Ilmu Pendidikan Universitas

Muhamadiyah Yogyakarta, 2010

M. Iskandar, Surini, Stategi Pembelajaran

Matematika, Jakarta: PT.Rinka Cipta , 1996

Pusat Bahasa Departemen Pendidikan

Nasional, Kamus Umum Bahasa Indonesia,

Jakarta: Balai Pustaka, 2007

Sunar Prasetyo, Dwi, "Yuk, Belajar

Matematika!” I, Yogyakarta : Power Books

(IHDINA), 2009 